\title{
Effect of the arbuscular mycorrhizal fungus Glomus intraradices on the false root-knot nematode Nacobbus aberrans in tomato plants
}

\author{
Paola Lax • Alejandra G. Becerra $\cdot$ Florencia Soteras • \\ Marta Cabello • Marcelo E. Doucet
}

Received: 5 July 2010 /Revised: 18 October 2010 /Accepted: 20 October 2010 /Published online: 14 December 2010

(C) Springer-Verlag 2010

\begin{abstract}
Information about the interaction between arbuscular mycorrhizal fungi (AMF) and the false root-knot nematode Nacobbus aberrans (Thorne, 1935) Thorne \& Allen, 1944 is scarce. The effect of Glomus intraradices Schenk \& Smith on tomato (Lycopersicon esculentum L.) cv. Platense inoculated with nematode juveniles from Lisandro Olmos (Argentina) was studied under greenhouse conditions. Six treatments with five replications were performed. After 80 days, nematode reproduction and percentage of AMF colonization in roots were estimated. Some plant growth parameters were also measured. In general, plants with AMF and AMF plus nematodes grew as well as the control without AMF and without nematodes. Furthermore, G. intraradices was beneficial in reducing nematode-induced damage in roots (lower number of galls) as well as in having a suppressive effect on parasite reproduction. This is the first study on the use of G. intraradices as a possible strategy in the control of $N$. aberrans in tomato.
\end{abstract}

Keywords Glomus intraradices $\cdot$ Lycopersicon esculentum - Nacobbus aberrans . Nematode reproduction . Mycorrhiza

P. Lax $(\bowtie) \cdot$ M. E. Doucet

Centro de Zoología Aplicada, Universidad Nacional de Córdoba,

Rondeau 798,

5000 Córdoba, Argentina

e-mail: plax@com.uncor.edu

\section{A. G. Becerra $\cdot$ F. Soteras}

IMBIV-CONICET, Facultad de Ciencias Exactas,

Físicas y Naturales, Universidad Nacional de Córdoba,

C.C. 495 ,

5000 Córdoba, Argentina

M. Cabello

Instituto Spegazzini, Facultad de Ciencias Naturales y Museo,

Avenida 53, No. 477,

1900 La Plata, Buenos Aires, Argentina

\section{Introduction}

Some species of plant-parasitic nematodes are a limiting factor in agricultural production in many parts of the world. Their wide host range, association with other organisms (fungi, bacteria, and viruses) in disease complex presents a very challenging problem damaging world's food supply (Saxena 2004). Chemical treatments are currently the most widely used and the reliable way of controlling these pests. However, the increasing use of toxic agrochemicals is being restricted (Djian-Caporalino et al. 2007). In the last years, biological control has become an efficient, economical, and non-polluting method of nematode control.

The arbuscular mycorrhizal symbiosis is a mutualistic association form between plants and wide variety of fungi from the phylum Glomeromycota. The symbiosis is formed by the majority of plants species and is found in ecosystems around the world (Wang and Qui 2006). Colonization of the root system by arbuscular mycorrhizal fungi (AMF) confers benefits directly to the hosts plant growth and development by increasing nutrient uptake and also improves plant tolerance to stress conditions and to the attack of soil-borne pathogens (Sharma et al. 2004). Regarding plant-parasitic nematodes, there is an interest in AMF-nematode interactions because they may enhance parasite resistance or tolerance of AMF-infected plants and their potential value for pest control (Hol and Cook 2005). The likelihood of using AMF in crop production systems is increasingly more realistic, and studies have increased considerably in the last years (Jaizme-Vega et al. 2002).

The false root-knot nematode, Nacobbus aberrans (Thorne, 1935) Thorne \& Allen, 1944, is a polyphagous species, sedentary endoparasite of roots. It is native to America (Sher 1970). Due to the severe damage it causes to agriculture, it is considered of quarantine importance 
(OEPP/EPPO 1984). Losses may reach between 10\% and $20 \%$ in sugar beet (Beta vulgaris L.) in USA (Inserra et al. 1996 ) and up to $73 \%$ in potato (Solanum tuberosum L.) in Peru and Bolivia (Canto-Saenz et al. 1996; Franco et al. 1996). To date, the presence of $N$. aberrans has been cited in Argentina, Bolivia, Chile, Ecuador, Mexico, Peru, and USA (Manzanilla-López et al. 2002).

N. aberrans was first detected in northwestern Argentina in 1977 parasitizing several crops and some weeds (Costilla et al. 1977). At present, it has a wide distribution and can be found infesting field-grown and greenhouse-grown crops (Doucet and Lax 2005). In the province of Córdoba, the parasite causes severe damage to tomato (Lycopersicon esculentum L.) and pepper (Capsicum annuum L.) under greenhouse conditions; plants usually exhibit poor development or wilting symptoms in shoot, or may even die when nematode population densities are high.

Most of the research works that evaluated AMF interaction with sedentary endoparasitic nematodes have focused on different root-knot nematode (Meloidogyne) species of economical importance. It has been observed that root colonization by Glomus spp. increased host plant tolerance to Meloidogyne spp. and showed a suppressive effect over nematode reproduction, as it occurred in banana (Musa AAA) (Jaizme-Vega et al. 1997; Elsen et al. 2002), tomato (Talavera et al. 2001; Shreenivasa et al. 2007), and olive (Olea europaea L.) (Castillo et al. 2006). AMF inoculation, however, is not always beneficial for the growth of plants infested by root-knot nematodes (Atilano et al. 1981) or for reduction of the parasite population (MacGuidwin et al. 1985; Atilano et al. 1981; Cofcewicz et al. 2001).

Information about interaction of $N$. aberrans and AMF is very scarce. The only published report indicates that tomato plants inoculated with Glomus sp. exhibited a lower number of galls induced by a Mexican population of the nematode (Gardezi et al. 1995). The objective of this work was to evaluate the possibility of using the mycorrhiza Glomus intraradices Schenk \& Smith as a protective agent against an isolate of $N$. aberrans on a susceptible tomato cultivar. The effects of the AMF-nematode interaction on tomato growth and pathogen development were also studied.

\section{Materials and methods}

Nematode isolate

An N. aberrans isolate from the locality of Lisandro Olmos (province of Buenos Aires, Argentina), of known capacity for multiplying on tomato, was employed for the study. Nematodes were maintained on tomato cv. Platense under greenhouse conditions. Plants were uprooted, and roots with galls were gently washed with running water to remove adhering soil particles. Egg masses were removed and placed in Petri dishes containing distilled water. They were maintained at room temperature to allow hatching, and then mobile second-stage juveniles (J2) were extracted with the aid of a pipette.

\section{AMF inoculum}

G. intraradices was selected because it showed beneficial effects when interacting with roots of certain plants in the presence of some species of plant-parasitic nematodes (Smith and Kaplan 1988; Jaizme-Vega and Pinochet 1997; Elsen et al. 2001).

The arbuscular mycorrhizal fungus [La Plata, Spegazzini Herbarium (LPS), culture Tierra del Fuego 28] was propagated on Medicago sativa L. Plants were grown for 6-12 months in pots containing a mixture of perlite and vermiculite (1:1). Plants were watered from below using a capillary system and fed with nutrient solution (three times a week) (Cabello 1997).

\section{Soil preparation}

Sandy loam soil was used for all experiments. Soil physicochemical characteristics were as follows: $\mathrm{pH}\left(\mathrm{H}_{2} \mathrm{O}\right), 5.20$; clay, $15 \%$; silt, $35 \%$; sand, $50 \%$; organic matter, $2.58 \%$; nitrogen, $0.22 \%$; and available $\mathrm{P}, 16.08 \mathrm{mg} \mathrm{kg}^{-1}$. The soil was air-dried, powdered, and sieved through a 2-mm-mesh sieve and was steam-sterilized three times $\left(120^{\circ} \mathrm{C}, 1 \mathrm{~h}\right.$ with $24 \mathrm{~h}$ between the three treatments). The steamed soil was mixed with autoclaved sand (60 $\mathrm{min}$ at a pressure of $2 \mathrm{~atm}$ ) in a $3: 1$ ratio.

\section{Plant material and treatments}

Tomato seeds (cv. Platense) were surface sterilized in $10 \%$ sodium hypochlorite $(\mathrm{NaOCl})$ for $5 \mathrm{~min}$ and sown in trays containing sterile soil to promote germination. One-month-old seedlings, which had four leaves, were placed individually in plastic containers $(20$-cm long $\times 4$-cm wide, with a capacity of $125 \mathrm{~g}$ of soil) containing a mixture of sterilized soil with sand (3:1). Six treatments were performed: (1) plants free of nematodes or AMF (control), (2) plants inoculated with the AMF $G$. intraradices at transplanting (zero time $=\mathrm{T}_{0}$ ), (3) plants inoculated with the nematode $N$. aberrans at $\mathrm{T}_{0}$, (4) plants inoculated with both $N$. aberrans and $G$. intraradices at $\mathrm{T}_{0},(5)$ plants inoculated with $N$. aberrans 3 weeks after transplanting, and (6) plants inoculated with $G$. intraradices at $\mathrm{T}_{0}$ and with $N$. aberrans 3 weeks after transplanting.

For nematode inoculation, roots were placed on the substrate and 100 active $\mathrm{J} 2$ (initial population $=\mathrm{Pi}$ ) present in $1.5 \mathrm{ml}$ of water were immediately deposited on the roots, 
which were then covered with the substrate. Inoculum of $G$. intraradices was composed of $5 \mathrm{~g}$ of a homogeneous mixture of rhizosphere soil, spores (approximately 1,000), and rootlets of the host plant, which were added through the planting hole at the time of transplanting. Five replications per treatment were performed. Temperature in the greenhouse was $24^{\circ} \mathrm{C}$ (10-h photoperiod). Plants were watered daily and were not fertilized. After 80 days, plants were uprooted and roots were gently washed with water to remove adhering particles.

Assessment of variables and data analysis

At the end of the experiment, the following plant growth parameters were measured: length and dry weight of root and shoot. The percentage of the arbuscular mycorrhiza colonization (\%AMC) was assessed according to the technique described by Phillips and Hayman (1970). Briefly, roots were cleared with $10 \% \mathrm{KOH}\left(15 \mathrm{~min}\right.$ at $\left.90^{\circ} \mathrm{C}\right)$, then acidified with $1 \%$ HCL ( $1 \mathrm{~min}$, root temperature) and stained in $0.05 \%$ trypan blue. Colonization was estimated by the grid-line intersect method (Giovannetti and Mosse 1980) in which 100 segments of $1 \mathrm{~cm}$ in length were evaluated under stereomicroscope Leica M420.

Roots of each plant were analyzed using stereoscopic microscope by counting the number of galls present. Root gall index (RGI) was estimated on the basis of the scale proposed for Meloidogyne spp. $(0=$ no galls, $1=1-2,2=3-$ $10,3=11-30,4=31-100$, and $5=$ more than 100 galls per root) (Hartman and Sasser 1985). An average of RGI $\leq 2$ was used as a possible indicator of resistance, following Hartman and Sasser (1985). Egg masses were extracted and submerged in $1 \%$ sodium hypochlorite solution for $4 \mathrm{~min}$ (Hussey and Barker 1973), and eggs were counted. Soil of each container was processed using the centrifugal-flotation technique (Jenkins 1964) for extraction of filiform nematodes present. Final nematode population density (Pf) was estimated based on the number of eggs counted plus the number of nematodes extracted from the soil. Population density was used to calculate the reproduction factor $(\mathrm{RF}=\mathrm{Pf} / \mathrm{Pi})($ Castillo et al. 1998).

The effect of AMF on nematode population (nematode response), which represents the percentage reduction in nematode numbers on AMF plants, was calculated as follows: the difference between nematode numbers on non-AMF plants and nematode numbers on AMF plants divided by the nematode numbers on non-AMF plants and multiplied by 100 (Hol and Cook 2005).

Plant growth and nematode parameters were analyzed by two-way analysis of variance and contrast test (Tukey, $P \leq$ 0.05 ) to determine the significance of mean differences between treatments. Those parameters that did not exhibit normality were transformed to $\log _{10}(x+1)$ before analysis.

\section{Results}

No AMF colonization was observed on the roots of nonmycorrhized plants. The remaining treatments inoculated with $G$. intraradices showed arbuscules, external and intracellular aseptate hyphae $(2-6 \mu \mathrm{m})$, oval to rectangular intracellular vesicles $(25-90 \mu \mathrm{m})$, and abundant coils (Fig. 1). Plant growth parameters showed significant differences among treatments, except shoot total length (Table 1). AMF colonization on the root system was significantly higher in plants inoculated with AMF and $N$. aberrans at $\mathrm{T}_{0}(\mathrm{AMF} \%=45.7)$ and after 3 weeks $(\mathrm{AMF} \%=$ 47.4) than in nematode-free plants $(\mathrm{AMF} \%=30)($ Table 1$)$. Inoculation with $G$. intraradices (AMF at $\mathrm{T}_{0}$ ) was associated only with increase in root length compared with the non-inoculated control. On the other hand, inoculation with $N$. aberrans (NEM at $\mathrm{T}_{0}$ ) reduced root and shoot dry weight compared with control. Moreover, plants inoculated with nematodes after 3 weeks (NEM after 3 weeks) increased total root length and reduced root dry weight compared with the non-inoculated control. No significant differences were observed among some growth parameters of plants inoculated only with nematodes and of those inoculated with nematodes and AMF (both at transplanting and after 3 weeks), except root total length (at $\mathrm{T}_{0}$ ) and root dry weight (after 3 weeks). The comparison of treatments $\mathrm{AMF}+\mathrm{NEM}$ on the two evaluation dates showed that plants that were inoculated with nematodes after 3 weeks exhibited an increase in biomass for shoot dry weight.

All the tomato plants inoculated with $N$. aberrans exhibited roots with galls induced by the nematode (Fig. 1). Both parameters associated with nematode reproduction exhibited significant differences among treatments (Table 1). The two treatments related to $N$. aberrans and AMF inoculation (at $\mathrm{T}_{0}$ and after 3 weeks) presented the lowest values of RGI and $\mathrm{RF}$, whereas the highest values corresponded to the respective control treatments (NEM at $\mathrm{T}_{0}$ and NEM after 3 weeks). A positive value of nematode response is an indicator of the decrease in the number of nematodes in mycorrhized plants. A 58.3\% reduction occurred when nematode and AMF inoculations were performed at $\mathrm{T}_{0}$, and a $23.7 \%$ reduction occurred when nematodes were inoculated in premycorrhized plants (compared with respective control: NEM after 3 weeks). Comparison of $N$. aberrans reproduction between the latter treatment performed (AMF at $\mathrm{T}_{0}+$ NEM after 3 weeks) and control NEM at $\mathrm{T}_{0}$ showed that nematode reproduction rate was reduced by $63.2 \%$.

\section{Discussion}

Chemical nematicides are prohibited due to their potentially detrimental effects on the environment and human health. 
Fig. 1 Arbuscular mycorrhizal colonization of $G$. intraradices in tomato cv. Platense infested by $N$. aberrans. a Arbuscule. b Coil. c Vesicles. d Tomato roots with galls induced by the nematode. Scale bars: a $10 \mu \mathrm{m} ; \mathbf{b}, \mathbf{c}$ $50 \mu \mathrm{m} ; \mathbf{d} 1 \mathrm{~cm}$
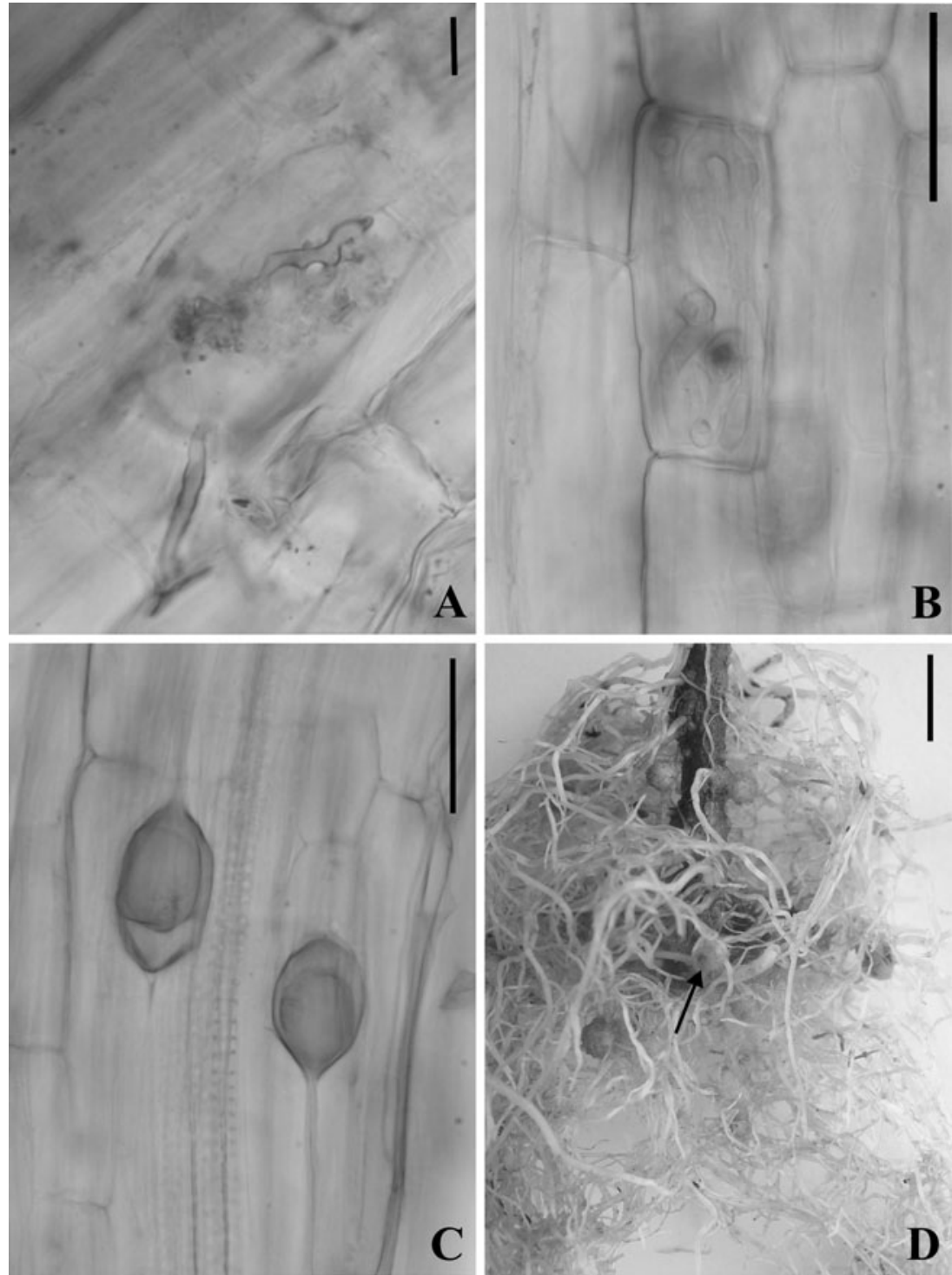

Table 1 Growth parameters of tomato plants cv. Platense, mycorrhizal root colonization of G. intraradices (AMF), RGI, and RF of $N$. aberrans (NEM)

\begin{tabular}{|c|c|c|c|c|c|c|c|}
\hline \multirow[t]{2}{*}{ Inoculation treatment } & \multirow{2}{*}{$\begin{array}{l}\text { Percentage } \\
\text { of AMF } \\
\text { colonization }\end{array}$} & \multicolumn{2}{|l|}{ Root } & \multicolumn{2}{|l|}{ Shoot } & \multirow[b]{2}{*}{ RGI } & \multirow[b]{2}{*}{$\mathrm{RF}$} \\
\hline & & Total length $(\mathrm{cm})$ & Dry weight (g) & Total length $(\mathrm{cm})$ & Dry weight $(\mathrm{g})$ & & \\
\hline Non-inoculated control & - & $20.3 \pm 1.4 \mathrm{a}$ & $0.6 \pm 0.1 \mathrm{~b}$ & $20.2 \pm 2.0 \mathrm{a}$ & $0.9 \pm 0.1 b$ & - & - \\
\hline $\mathrm{AMF}$ at $\mathrm{T}_{0}$ & $30.0 \pm 10.3 \mathrm{a}$ & $24.9 \pm 2.2 b$ & $0.3 \pm 0.2 \mathrm{ab}$ & $20.4 \pm 1.5 \mathrm{a}$ & $0.8 \pm 0.1 \mathrm{~b}$ & - & - \\
\hline $\mathrm{NEM}$ at $\mathrm{T}_{0}$ & - & $20.5 \pm 0.9 \mathrm{a}$ & $0.2 \pm 0.1 \mathrm{a}$ & $21.0 \pm 3.2 \mathrm{a}$ & $0.3 \pm 0.1 \mathrm{a}$ & $2.6 b$ & $42.8 b$ \\
\hline $\mathrm{AMF}$ at $\mathrm{T}_{0}+\mathrm{NEM}$ at $\mathrm{T}_{0}$ & $45.7 \pm 7.1 b$ & $24.1 \pm 3.7 \mathrm{ab}$ & $0.2 \pm 0.3 \mathrm{a}$ & $20.1 \pm 1.6 \mathrm{a}$ & $0.3 \pm 0.1 \mathrm{a}$ & $1.6 \mathrm{a}$ & $17.9 \mathrm{a}$ \\
\hline NEM after 3 weeks & - & $21.8 \pm 1.9 \mathrm{ab}$ & $0.5 \pm 0.1 \mathrm{ab}$ & $19.6 \pm 0.4 \mathrm{a}$ & $1.0 \pm 0.04 \mathrm{~b}$ & $2.8 \mathrm{~b}$ & $20.7 \mathrm{ab}$ \\
\hline $\mathrm{AMF}$ at $\mathrm{T}_{0}+\mathrm{NEM}$ after 3 weeks & $47.4 \pm 5.1 \mathrm{~b}$ & $20.8 \pm 2.0 \mathrm{ab}$ & $0.2 \pm 0.04 \mathrm{a}$ & $17.6 \pm 1.7 \mathrm{a}$ & $0.9 \pm 0.2 b$ & $2.4 \mathrm{ab}$ & $15.8 \mathrm{a}$ \\
\hline
\end{tabular}

Data are means of five replicates. Means in the same column followed by the same letter did not differ according to a Tukey test $(P \leq 0.05)$

$T_{0}$ transplanting time 
The use of AMF as biological control of plant-parasitic nematodes is therefore an attractive option to minimize nematode-induced damages (Zhang et al. 2008). The present work is the first evaluation of the effect of $G$. intraradices on tomato plants as a possible tool to control the attack by $N$. aberrans.

The use of $G$. intraradices in tomato plants inoculated with $N$. aberrans juveniles showed significant differences among some growth parameters. In general, plants with $\mathrm{AMF}$ and $\mathrm{AMF}+\mathrm{NEM}$ grew as well as the control without AMF and without nematodes. Similar situations have been reported by Hol and Cook (2005). An overview of AMFnematode interactions based on data from previous studies revealed that plant responses to inoculation with plantparasitic nematodes and AMF together differed among nematodes with different feeding types (ectoparasites, sedentary and migratory endoparasites). AMF plants suffered more from ectoparasites than non-AMF plants, while this was opposite for endoparasites (Hol and Cook 2005).

Nematode presence may increase, decrease, or have no effect on root colonization by AMF (Roncadori 1997). The effect would depend on the specific fungal species involved (Waceke et al. 2001). In the present work, lower $G$. intraradices colonization was observed in the absence of $N$. aberrans. Plants inoculated with AMF plus the nematode showed a $52 \%$ increase in root colonization $\left(A M F\right.$ at $\mathrm{T}_{0}+\mathrm{NEM}$ at $\left.\mathrm{T}_{0}\right)$ and a $58 \%$ increase (AMF at $\mathrm{T}_{0}+$ NEM after 3 weeks) relative to control (AMF at $\mathrm{T}_{0}$ ). Reports of plants parasitized by Meloidogyne incognita (Kofoid \& White, 1919) Chitwood, 1949 indicated a slight increase in root colonization by Glomus mosseae (Nicol. \& Gerd.) Gerdemann \& Trappe in banana "Grand Naine" (Jaizme-Vega et al. 1997) and Gigaspora margarita Becker \& Hall on soybean (Glycine max (L.) Merr.) (Carling et al. 1989). In the latter case, the nematode also tended to stimulate sporulation by AMF. However, in other situations, AMF colonization has been reduced in the presence of rootknot nematodes, such as tomato infested by Meloidogyne javanica (Treub, 1885) Chitwood, 1949 and inoculated with Gigaspora margarita (Cofcewicz et al. 2001), pyrethrum (Chrysanthemum cinerariefolium Vis.) inoculated with Glomus sp. and attacked by Meloidogyne hapla Chitwood, 1949 (Waceke et al. 2001), or grape (Vitis vinifera L.) roots with Glomus fasciculatum (Thaxter) Ger. \& Trappe emend. Walker and Koske and Meloidogyne arenaria (Neal, 1889) Chitwood, 1949 (Atilano et al. 1981). In these cases, the degree to which plant-parasitic nematodes, especially Meloidogyne spp., affect mycorrhizae may depend on the effects of nematodes on the plants, rather than on direct effects on fungi (Atilano et al. 1981). The parasite may have obstructed nutrient flow between symbionts, reducing fungus development and efficiency (Cofcewicz et al. 2001).
G. intraradices inoculation was highly beneficial for the host in reducing the damage caused by the nematode in roots (lower number of galls). The highest RGI was recorded in the absence of AMF; in its presence, RGI decreased by $38.5 \%$ at $\mathrm{T}_{0}$ and in the treatment performed after 3 weeks, by $14.3 \%$. Reduction in the number of galls due to the effect of AMF agrees with results indicated in the only experiment conducted so far in tomato infected by $N$. aberrans and inoculated with Glomus sp. (Gardezi et al. 1995). Although RGI was reduced in root systems colonized by $G$. intraradices, the most important effect was observed in the considerable decrease of parasite multiplication rate $\left(58.2 \%\right.$ at $\mathrm{T}_{0}, 23.7 \%$ in the treatment performed after 3 weeks and up to $63 \%$ when the latter treatment is compared with control NEM at $\mathrm{T}_{0}$ ). Results agree with previous reports on the suppression of different nematode species by AMF (including G. intraradices), such as Pratylenchus goodeyi Sher \& Allen, 1953 and M. incognita in banana (Jaizme-Vega et al. 1997; Jaizme-Vega and Pinochet 1997), M. incognita and M. javanica in olive (Castillo et al. 2006), M. incognita in tomato (Talavera et al. 2002), Radopholus citrophilus Huettel, Dickson \& Kaplan, 1984 in rough lemon citrus (Smith and Kaplan 1988), and Radopholus similis Cobb, 1893 and Pratylenchus coffeae (Zimmerman, 1898) Filipjev \& Schuurmans Stekhoven, 1941 in carrot root cultures (Daucus carota L.) (Elsen et al. 2001, 2003). Mechanisms involved in nematode suppression by AMF are still a matter of speculation (Elsen et al. 2002). Some possible factors include enhanced nutrient status of the plant, biochemical changes in plant tissue, anatomical changes, modified root exudation, and changes induced in root morphology (Hooker et al. 1994).

In the present work, the lowest reproduction of $N$. aberrans was obtained in the treatment involving pre-mycorrhized plants and further attacked by nematode juveniles. Because no tomato cultivars resistant to $N$. aberrans have been obtained so far, this approach involving AMF-nematode interactions might represent an effective nematode management strategy in commercial tomato production, particularly in continuous cropping under greenhouse conditions. Although the study was not repeated, our results demonstrate the possible advantage of a previous application of AMF inoculum in the soil devoted to develop tomato seedbeds. Thus, once the plant is transplanted to the field or greenhouse in soil infested by $N$. aberrans, the roots would already be colonized by AMF. This would confer the plant with certain degree of tolerance to the pathogen attack and, at the same time, would contribute to limit nematode population densities in the soil. However, as sterilized soil was used, it should be taken into account that other native soil microbes might affect the mycorrhizosphere.

$N$. aberrans populations exhibit a great variation on behavior, either on a single host or on a range of plants 
(Manzanilla-López et al. 2002; Lax et al. 2006). Therefore, there are different races within the species (Inserra et al. 1985; Castiblanco et al. 1999; Manzanilla-López et al. 2002). On the other hand, some AMF species have proved to be more efficient, to a greater or lesser degree, than others in suppressing plant-parasitic nematodes (Waceke et al. 2001; Hol and Cook 2005). For this reason, it is important to conduct further studies in this field, incorporating other nematode populations with different degree of pathogenicity; it is also important to evaluate their interaction with other mycorrhizal species and/or isolates as well as with other plant species of importance for agriculture.

Acknowledgements This work was financially supported by the Agencia Córdoba Ciencia S. E. (Province of Córdoba, Argentina). The authors thank Dr. Guillermo Cap (IPAF Pampeana-INTA, Province of Buenos Aires, Argentina) for providing the nematode population. Dr M. Cabello is a researcher of the CIC.

\section{References}

Atilano RA, Menge JA, Van Gundy SD (1981) Interaction between Meloidogyne arenaria and Glomus fasciculatus in grape. J Nematol 13:52-57

Cabello MN (1997) Hydrocarbon pollution: its effect on native arbuscular mycorrhizal fungi (AMF). FEMS Microbiol Ecol 22:233-236

Canto-Saenz M, Arcos MJ, Jatala P, Haddad R (1996) Morphology, biology, and management of Nacobbus aberrans in Peru. Nematropica 26:197

Carling DE, Roncadori RW, Hussey RS (1989) Interactions of vesicular-arbuscular mycorrhizal fungi, root-knot nematode, and phosphorus fertilization on soybean. Plant Dis 73:730-733

Castiblanco O, Franco J, Montecinos R (1999) Razas y gama de hospedantes en diferentes poblaciones del nematodo Nacobbus aberrans (Thorne, 1935), Thorne \& Allen, 1944. Rev Latinoam Papa 11:85-96

Castillo P, Vovlas N, Jiménez-Díaz RM (1998) Pathogenicity and histopathology of Pratylenchus thornei populations on selected chickpea genotypes. Plant Pathol 47:370-376

Castillo P, Nico AI, Azcón-Aguilar C, Del Río Rincón C, Calvet C, Jiménez-Díaz RM (2006) Protection of olive planting stocks against parasitism of root-knot nematodes by arbuscular mycorrhizal fungi. Plant Pathol 55:705-713

Cofcewicz ET, Medeiros CAB, Carneiro RMDG, Pierobom CR (2001) Interação dos fungos micorrízicos arbusculares Glomus etunicatum e Gigaspora margarita e o nematóide das galhas Meloidogyne javanica em tomateiro. Fitopatol bras 26:65-70

Costilla MA, de Ojeda SG, de Gomez TH (1977) Contribución al estudio del falso nematodo del nudo Nacobbus aberrans. Nematropica 7:7-8

Djian-Caporalino C, Fazari A, Arguel MJ, Vernie T, VandeCasteele C, Faure I, Brunoud G, Pijarowski L, Palloix A, Lefebvre V, Abad P (2007) Root-knot nematode (Meloidogyne spp.) Me resistance genes in pepper (Capsicum annuиm L.) are clustered on the P9 chromosome. Theor Appl Genet 114:473-486

Doucet ME, Lax P (2005) El género Nacobbus Thorne \& Allen, 1944 en Argentina. 6. La especie N. aberrans (Thorne, 1935) Thorne \& Allen, 1944 (Nematoda: Tylenchida) y su relación con la agricultura. An Acad Nac Agronomía Vet 59:5-45
Elsen A, Declerck S, De Waele D (2001) Effects of Glomus intraradices on the reproduction of the burrowing nematode (Radopholus similis) in dixenic culture. Mycorrhiza 11:49-51

Elsen A, Declerck S, De Waele D (2002) Effect of three arbuscular mycorrhizal fungi on root-knot nematode (Meloidogyne spp.) infection of Musa. Infomusa 11:21-23

Elsen A, Declerck S, De Waele D (2003) Use of root organ cultures to investigate the interaction between Glomus intraradices and Pratylenchus coffeae. Appl Environ Microbiol 69:4308-4311

Franco J, Ortuño N, Oros R, Main G (1996) Biology and management of Nacobbus aberrans on potato in Bolivia. Nematropica 26:204

Gardezi AK, Zavaleta-Mejia E, Garcia R, Ferrera-C R, Perez CA (1995) Efecto de endomicorrizas sobre la infección de Nacobbus aberrans en jitomate (Lycopersicon esculentum). Memorias XXII Congreso Nacional de Fitopatología, Guadalajara

Giovannetti M, Mosse B (1980) An evaluation of techniques for measuring vesicular-arbuscular mycorrhizal infection in roots. New Phytol 84:489-500

Hartman KM, Sasser JN (1985) Identification of Meloidogyne species on the basis of differential host test and perineal-pattern morphology. In: Barker KR, Carter CC, Sasser JN (eds) An advanced treatise on Meloidogyne. Volume II: Methodology. Raleigh. North Carolina State University Graphics and USAID, North Carolina, pp 69-77

Hol HWG, Cook R (2005) An overview of arbuscular mycorrhizal fungi-nematode interactions. Bas Appl Ecol 6:489-503

Hooker JE, Jaizme-Vega MC, Atkinson D (1994) Biocontrol of plant pathogens using arbuscular mycorrhizal fungi. In: Gianinazzi S, Schüepp H (eds) Impact of arbuscular mycorrhizas on sustainable agriculture and natural ecosystems. Birkhäuser Verlag, Basel, pp 191-200

Hussey RS, Barker KR (1973) A comparison of methods of collecting inocula of Meloidogyne spp., including a new technique. Plant Dis Rep 57:1025-1028

Inserra RN, Griffin GD, Anderson JL (1985) The false root-knot nematode Nacobbus aberrans. Research Bulletin 510. Utah State University, Logan, p 14

Inserra RN, Griffin GD, Kerr ED (1996) Geographical distribution and economic importance of Nacobbus spp. in the United States. Nematropica 26:207

Jaizme-Vega MC, Pinochet J (1997) Growth response of banana to three mycorrhizal fungi in Pratylenchus goodeyi infested soil. Nematropica 27:69-76

Jaizme-Vega MC, Tenoury P, Pinochet J, Jaumot M (1997) Interactions between the root-knot nematode Meloidogyne incognita and Glomus mosseae in banana. Plant Soil 196:27-35

Jaizme-Vega MC, Esquivel Delamo M, Tenoury Domínguez P, Rodríguez Romero AS (2002) Effects of mycorrhization on the development of two cultivars of micropropagated banana. Infomusa 11:25-28

Jenkins WR (1964) A rapid centrifugal-flotation technique for separating nematodes from soil. Plant Dis Rep 48:692

Lax P, Doucet ME, Braga R, Gioria R (2006) Response of different pepper varieties to attack by two populations of Nacobbus aberrans. Nematol Bras 30:259-265

MacGuidwin AE, Bird GW, Safir GR (1985) Influence of Glomus fasciculatum on Meloidogyne hapla infecting Allium cepa. J Nematol 17:389-395

Manzanilla-López RH, Costilla MA, Doucet M, Franco J, Inserra RN, Lehman PS, Cid del Prado-Vera I, Souza RM, Evans K (2002) The genus Nacobbus Thorne \& Allen, 1944 (Nematoda: Pratylenchidae): systematics, distribution, biology and management. Nematropica 32:149-227

OEPP/EPPO (1984) Data sheets on quarantine organisms No. 144, Nacobbus aberrans. Bull OEPP/EPPO Bull 14:61-66 
Phillips JM, Hayman DS (1970) Improved procedures for clearing roots and staining parasitic and vesicular-arbuscular mycorrhizal fungi for rapid assessment of infection. Trans Br Mycol Soc $55: 158-161$

Roncadori RW (1997) Interactions between arbuscular mycorrhizas and plant parasitic nematodes en agro-ecosystems. In: Gange AC, Brown VK (eds) Multitrophic interactions in terrestrial systems: 36th Symposium of the British Ecological Society. Blackwell, Oxford, pp 101-113

Saxena G (2004) Biocontrol of nematode-borne diseases in vegetable crops. In: Mukerji KG (ed) Disease management of fruits and vegetables: fruit and vegetable diseases, vol 1. Kluwer, Alphen aan den Rijn, pp 397-450

Sharma MP, Gaur A, Tanu U, Sharma OP (2004) Prospects of arbuscular mycorrhiza in sustainable management of root- and soil-borne diseases of vegetable crops. In: Mukerji KG (ed) Disease management of fruits and vegetables: fruit and vegetable diseases, vol 1. Kluwer, Alphen aan den Rijn, pp 501-539

Sher SA (1970) Revision of the genus Nacobbus Thorne and Allen, 1944 (Nematoda: Tylenchoidea). J Nematol 2:228-235

Shreenivasa KR, Krishnappa K, Ravichandra NG (2007) Interaction effects of arbuscular mycorrhizal fungus Glomus fasciculatum and root-knot nematode, Meloidogyne incognita on growth and phosphorous uptake of tomato. Karnataka J Agric Sci 20:57-61

Smith GS, Kaplan DT (1988) Influence of mycorrhizal fungus, phosphorus, and burrowing nematode interactions on growth of rough lemon citrus seedlings. J Nematol 20:539-544

Talavera M, Itou K, Mizukubo T (2001) Reduction of nematode damage by root colonization with arbuscular mycorrhiza (Glomus spp.) in tomato-Meloidogyne incognita (Tylenchida: Meloidogynidae) and carrot-Pratylenchus penetrans (Tylenchida: Pratylenchidae) pathosystems. Appl Entomol Zool 36:387-392

Talavera M, Itou K, Mizukubo T (2002) Combined application of Glomus sp. and Pasteuria penetrans for reducing Meloidogyne incognita (Tylenchida: Meloidogynidae) populations and improving tomato growth. Appl Entomol Zool 37:61-67

Waceke JW, Waudo SW, Sikora R (2001) Response of Meloidogyne hapla to mycorrhiza fungi inoculation on pyrethrum. Afr J Sci Technol 2:63-70

Wang B, Qui Y-L (2006) Phylogenetic distribution and evolution of mycorrhizas in land plants. Mycorrhiza 16:299-363

Zhang L, Zhang J, Christie P, Li X (2008) Pre-inoculation with arbuscular mycorrhizal fungi suppresses root knot nematode (Meloidogyne incognita) on cucumber (Cucumis sativus). Biol Fertil Soils 45:205-211 